\title{
Committee on the Woman, Family and Childhood in the Iraqi Parliament (Observation and Assessment)
}

\author{
Inass Abdulsada Ali ${ }^{1}$, Sana Kadhem Qati ${ }^{2}$, Batool Hussain Alwan ${ }^{2}$ \\ ${ }^{1}$ International Studies, College of Political Science/University of Baghdad, Baghdad, Iraq \\ ${ }^{2}$ Political Thought, College of Political Science/University of Baghdad, Baghdad, Iraq \\ Email: inass3a@copolicy.uobaghdad.edu.iq
}

How to cite this paper: Ali, I. A., Qati, S. K., \& Alwan, B. H. (2018). Committee on the Woman, Family and Childhood in the Iraqi Parliament (Observation and Assessment). Open Journal of Political Science, 8 , 263-277.

https://doi.org/10.4236/ojps.2018.83019

Received: April 16, 2018

Accepted: July 14, 2018

Published: July 17, 2018

Copyright $\odot 2018$ by authors and Scientific Research Publishing Inc. This work is licensed under the Creative Commons Attribution International License (CC BY 4.0).

http://creativecommons.org/licenses/by/4.0/

(c) (i) Open Access

\begin{abstract}
When the Iraqi parliament was formed after 2003, women had their share in this importance, as they were present always in the conducts of the newborn political process in Iraq due to the political democratization. Soon after the first legislative elections occurred in 2005, lights were shed on naming and forming committees, one of which was a committee on the woman, family, and child, which was renamed afterward into committee on the woman, family, and childhood. By observing the work of this committee in two legislative sessions, this research is aimed at introducing a pioneering study in this field for its importance and the rarity of similar studies that tackled it directly. The paper will recognize the committee's role and response to issues within its range of responsibilities, especially women's issues, and answers two significant questions: is the committee activated or deactivated? And is it active or inactive? Our paper tries to confirm the authenticity of its presumption which is "Committee on Woman, Family, and Childhood is considered inactive because it is deactivated due to the number of draft laws that were suggested through the two parliamentary sessions and its capability of passing some of them". Our qualitative and quantitative approaches relied on using documents analysis tool such as parliament basic system, internal committee regulations and parliament sessions' proceedings that discussed draft laws suggested by the committee, etc. We also made direct interviews with members of the committee in the previous and the current sessions of parliament. But there lie a lot of difficulties in the face of these plans; for example, chairman of the committee in second legislative sessions canceled an appointment with the researchers, after we went to meet her on time in that appointment.
\end{abstract}

\section{Keywords}

Parliamentary Committees, Iraqi Parliament, Committee on the Women, 
Family and Childhood

\section{Introduction}

Parliamentary committees are a democratic necessity in the political regimes that depend on democracy as a way of ruling and organizing the relations between the state and people. This necessity emerges from the nature of the parliamentary work as an authority that supervises the government actions and prepares draft laws for discussion in which they are adopted. Thus, the committees' issues are of huge importance because the latter is its core work and it will provide a friction with those involved.

When the Iraqi parliament was formed after 2003, women had their share in this importance, as they were present always in the conducts of the newborn political process in Iraq due to the political democratization. Soon after the first legislative elections occurred in 2005, lights were shed on naming and forming committees, one of which was a committee on the woman, family, and child which was renamed afterward into committee on the woman, family, and childhood.

By observing the work of this committee in two legislative sessions, this research is aimed at introducing a pioneering study in this field for its importance and the rarity of similar studies that tackled it directly. Almost all of the previous studies that are relevant to our research focus on women issues and tackle Iraqi women's political participation, her parliamentary representation and performance. However, the only study that indirectly makes mentions of the woman committee, is the study of Nahla Alnidawy (2010) entitled "Iraqi woman parliamentary performance". In addition, there are few studies that deal with women in parliament in general, most prominent of them the study of Bilqis Mohammed Jawad (2012), entitled "The Role of Iraqi Woman in the Democratic System: An Analytical Study of Women's Parliamentary Behavior" and a paper presented by a researcher in research department in the Iraqi parliament, Aseel Salman (2008) entitled "The Role of Iraqi Woman in the Iraqi Parliament since 2003". We cannot forget to mention the study of Samira Jafar Al-Moussawi (2009), the chairman of the committee in first parliamentary session (2005-2009) entitled "Towards a Future Vision for the Process of Change and Social Development in the Field of Women and Childhood: An Attempt to Change and Develop the Iraqi Social Structure for the Advancement of Women and Children" which is published in 2009 after the end of the parliamentary session, Al-Moussawi benefited from her experience as a chairman of the committee to write about the ways through which can improve and develop the situation of women and children.

Therefore, the paper is unique because it is based on the questions raised through the parliamentary experience and the woman permanent parliamentary 
committee and it tries to find answers to these questions. The paper will recognize the committee's role and response to issues within its range of responsibilities, especially women's issues, and answers two significant questions: is the committee activated or deactivated? And is it active or inactive? The paper tries to confirm the authenticity of its presumption which is "Committee on Woman, Family, and Childhood is considered inactive because it is deactivated due to the number of draft laws that were suggested through the two parliamentary sessions and its capability of passing some of them". Our qualitative and quantitative approaches relied on using documents analysis tool such as parliament basic system, committee's rules of procedure and parliament sessions' proceedings that discussed draft laws suggested by the committee, etc. We also made direct interviews with members of the committee in the previous and the current sessions of parliament. But there lie a lot of difficulties in the face of these plans; for example, chairman of the committee in second legislative sessions canceled an appointment with the researchers, after we went to meet her on time in that appointment.

The paper is also divided into three parts. The first part introduces legislations of the Iraqi council of representatives' rules of procedure especially those related to forming permanent parliamentary committees and the committee's rules of procedure. The second part sheds lights on the activities of the committee. While the third part is assigned to assess the committee's function concerning its formation and work on which our observation of the presumed deficiencies of the committee is based.

\section{The Formation and Development ${ }^{1}$}

In general issues concerning woman, child and family in modern day are one of the most debatable issues in the international community and in Iraqi in particular after the changes happened in Iraq since 2003. The civil society organizations and active feminine movements that appeared had adopted the above issues in all its dimensions. Iraqi civil society raised the concern about women and children and family's rights resulting in legislating laws to ensure viable solutions to most, if not all, problems from which they previously suffered and grant rights to these segments of society that were previously deprived.

These informal non-governmental efforts evoked the government to respond to these issues positively in particular women's issue in particular, and child and family's issues in general by increasing awareness and turning attention to these issues, their cause and effects and solutions to the existing problems. This led to the formation of the ministry of state for women's affairs a new governmental ministry to be in charge with these issues. Although this was a ministry without portfolio, the formation of the committee on woman, family, and childhood was approved as one of the permanent parliamentary committees. As a result, the Iraqi council of representatives voted for an inner system in the parliament se-

${ }^{1}$ This part depends on Iraqi parliament website in the Internet http://www.parliament.iq. 
venth hearing held in the fifteenth of June 2006/first session. This was embodied in the twelfth chapter, article (70) that specialized the techniques of formation and work of parliamentary committees. The legislation provided for the formation of 24 committees including the committee on the woman, family, and childhood.

Article (69) in the same chapter took into consideration the will of the member, his specialization, and experience when permanent committees are formed. While article (72/1) granted the right to each MP to nominate for membership or chairing these committees. The same article organized the way of choosing those in its second provision by exposing names of candidates of each of the permanent committees to the council to vote for them in one list, which gains consensus by parliamentary blocs.

In the thirteenth chapter of the parliament's rules of procedure entitled "permanent committees specialties" the tasks of these committees are delineated. Article (107) is assigned for the woman, household and childhood committee tasks which are as follows:

First: presenting suggested draft laws that support woman's role and her position in society and also her political progress.

Second: caring for woman rights and defending it according to human rights bills with consideration to Iraqi society privacy.

Third: Observing violations of executive authority institutions to woman rights mentioned in the constitution.

Forth: supervising executing laws and preceding that protect the family in the Iraqi society.

Fifth: caring for developing laws and draft laws that look after maternity and childhood.

Sixth: caring for and looking after youths in order to prevent them from deviation and homelessness.

Seventh: Supervising social welfare institutions to ensure persons with special needs, disabled and elderlies rights.

The rules procedure of the committee on women, family, and childhood that is applied until now is in conformity with provisions of the parliament's rules of procedure. Article (4) of the committee's rules of procedure stated that the committee practices its field of specialization laid down in the article (107) of the parliament's rules of procedure with other similar articles. Also, article (18) delineated the same specializations of the committee that mentioned in the article (107) of the parliament's rules of procedure.

Chapter six of the committee's rules of procedure delineated its mechanisms according to articles (19) and (20), as article (19) delineated the committee's mechanism legislatively such as suggesting laws, studying draft laws and supporting suggestions and enactments from other committees that are similar in interests and specializations, etc.

Article (20) delineated the supervisory mechanism of the committee such as 
inviting any minister or those of his rank, undersecretaries, those with special ranks and other government employees for explanation and seeking information. It can ask state institutions and civil society organizations for documents and information it needs. It pursues and supervises maintaining balance in related institutions with its specialization, besides following up related ministers statements. It also supervises the ministry of labor and social affairs and the ministry of state for women affairs and all their affiliated institutions in which it observes all violations.

The rules of procedure of the mentioned committee defined the way of its formation which conforms to the provisions of the council of the parliament rules of procedure concerning creating and forming permanent committees especially the number of their members. Article (3) of the committee's rules of procedure stated that committee is composed of seven members elected according to the parliament rules of procedure. Article (11) mentioned that committee on the woman, family, and childhood is composed of:

1) Chairman of the committee.

2) Vice-chairman of the committee.

3) Committee Rapporteur.

4) Committee members elected according to the parliament's rules of procedure.

The two tables (Table $1 \&$ Table 2) show the membership of the committee on the woman, family, and childhood in two electoral sessions, the first is from 2005-2009, the second is from 2010-2014 with some basic information that will be debated in the next parts of this research and will be referred to in its due time.

Table 1. Names of Committee on Woman, Family and Childhood members in the first electoral session 2005-2009 and their political affiliation and academic attainment.

\begin{tabular}{|c|c|c|c|c|}
\hline No. & $\begin{array}{l}\text { Member of } \\
\text { parliament name }\end{array}$ & $\begin{array}{l}\text { Her status in the } \\
\text { committee }\end{array}$ & Political affiliation & Academic attainment \\
\hline 1 & $\begin{array}{l}\text { Samira Jaffar } \\
\text { Al-Musawi }\end{array}$ & $\begin{array}{l}\text { Chairman of the } \\
\text { committee }\end{array}$ & $\begin{array}{l}\text { Independents/United } \\
\text { Iraqi alliance Sa'dri } \\
\text { trend }\end{array}$ & $\begin{array}{c}\text { Bachelor of petroleum } \\
\text { engineering }\end{array}$ \\
\hline 2 & Majida Hussein Disher & $\begin{array}{l}\text { Vice-chairman of } \\
\text { the committee }\end{array}$ & Badr organization & Bachelor of medicine \\
\hline 3 & $\begin{array}{c}\text { Nidhal Ta'an died and } \\
\text { was replaced with } \\
\text { Lamia Naeema } \\
\text { Dawood }\end{array}$ & Member & $\begin{array}{l}\text { Independents/United } \\
\text { Iraqi alliance }\end{array}$ & Bachelor of physics \\
\hline 4 & Nadira Ayef Habeeb & Member & Accord front & Bachelor of arts \\
\hline 5 & $\begin{array}{c}\text { Nada Muhammad } \\
\text { Ibrahim }\end{array}$ & Member & $\begin{array}{l}\text { Iraqi front for national } \\
\text { dialogue }\end{array}$ & Anesthesia high diploma \\
\hline 6 & Ina'am Muhammad Ali & Member & $\begin{array}{l}\text { Independents/United } \\
\text { Iraqi alliance }\end{array}$ & Bachelor of science \\
\hline 7 & Barween Salih & Member & Kurdistan alliance & Preparatory \\
\hline
\end{tabular}

The researchers prepare the table by relying on the Iraqi Parliament website http://www.parliament.iq/. 
Table 2. Names of Committee on Woman, Family and Childhood members in the second electoral session 2010-2014 and their political affiliation and academic attainment ${ }^{2}$.

\begin{tabular}{|c|c|c|c|c|}
\hline No. & Name of the MP & $\begin{array}{l}\text { Her status in the } \\
\text { committee }\end{array}$ & Political affiliation & Academic attainment \\
\hline 1 & 1-Intisar Ali Khuder & $\begin{array}{l}\text { Chairman of the } \\
\text { committee }\end{array}$ & Iraqiya alliance & Bachelor of law \\
\hline 2 & 2-Shafaa Adil Younis & $\begin{array}{l}\text { Vice-chairman of the } \\
\text { committee }\end{array}$ & Iraqiya alliance & Teacher training institute \\
\hline 3 & $\begin{array}{l}\text { Haifaa Naseem } \\
\text { Muhammad Ali }\end{array}$ & $\begin{array}{l}\text { Rapporteur of the } \\
\text { committee }\end{array}$ & $\begin{array}{l}\text { Sa'adri trend/National } \\
\text { alliance }\end{array}$ & Bachelor of law \\
\hline 4 & $\begin{array}{c}\text { Huda Sayad } \\
\text { Mahmood Shakir }\end{array}$ & Member & $\begin{array}{l}\text { Islamic da'waa party } \\
\text { /National alliance }\end{array}$ & Bachelor of chemistry \\
\hline 5 & Hayfaa Majli Jaffar & Member & $\begin{array}{l}\text { Independents/National } \\
\text { alliance }\end{array}$ & $\begin{array}{c}\text { Bachelor of } \\
\text { administration and } \\
\text { economy/bachelor of law }\end{array}$ \\
\hline 6 & $\begin{array}{l}\text { Manal Hameed } \\
\text { Hashim }\end{array}$ & Member & $\begin{array}{l}\text { Independents/National } \\
\text { alliance }\end{array}$ & Teacher training institute \\
\hline 7 & $\begin{array}{c}\text { Amel Sahib Hassan } \\
\text { Hussein }\end{array}$ & Member & $\begin{array}{l}\text { Islamic da'waa party } \\
\text { /National alliance }\end{array}$ & $\begin{array}{c}\text { Bachelor of } \\
\text { administration and } \\
\text { economy }\end{array}$ \\
\hline
\end{tabular}

The researchers prepare the table by relying on the Iraqi Parliament website http://www.parliament.iq.

\section{The Committee's Activities ${ }^{3}$}

The committee did many activities throughout the first and second parliamentary sessions according to first the inner system of the council of representatives in articles $(87,107)$ and second to what had been stated in the internal regulations of the committee on women, family and childhood in delineating its terms of reference.

\subsection{First Parliamentary Session's Activities}

In the first session, the committee presented draft laws; we will refer to the most important ones listed in Table 3.

Above that, the committee followed up the stages of completing the laws of (labor, social and health insurance related to the ministry of labor and social affairs). It recommended that the ministry include the divorced, widowers and other segments with the financial aid of social protection network to which the ministry responded. Also, the committee recommended a raise in salaries for

${ }^{2}$ In the parliamentary hearing number (24) dated in 17/1/2011, they voted upon forming permanent parliamentary committees including committee on woman, family and childhood for the second electoral session. It is worth mentioning that membership of this committee under study was not as it occurred in the table. The record of the parliamentary hearing number (24) mentioned that it was voted for formation of the committee consisting of 1-Mrs. Samira Al-Musawi2-Mrs. Hayfaa Naseem 3-Mrs. Intisar Ali khudhair 4-Mrs. Lubna Raheem 5-Mrs. Faeeza Al-Ubaidi 6-Mrs. Shafaa Adil 7-Mrs. Huda Sajad. Number (1) who was the chairman of the committee in the first electoral session withdrew, and was elected vice-chairman of the second committee in its first meeting in $2 / 2 / 2011$, and number (4) and (5), they were replaced by others.

${ }^{3}$ Information mentioned in this part are taken from the Iraqi parliament formal website in the internet: http://www.parliament.iq. 
Table 3. Draft laws submitted by the Committee and the Laws approval by Iraqi Parliament in the session of 2005-2009.

\begin{tabular}{|c|c|c|c|c|c|c|c|}
\hline No. & Draft law & The Source & $\begin{array}{l}\text { The committee to which } \\
\text { the draft law has been } \\
\text { forwarded }\end{array}$ & $1^{\text {st }}$ Reading & $2^{\text {nd }}$ Reading & Voting & Approval \\
\hline 1 & $\begin{array}{l}\text { Law of those with } \\
\text { special needs }\end{array}$ & & $\begin{array}{l}\text { Woman, household and } \\
\text { childhood committee }\end{array}$ & & & & \\
\hline 2 & $\begin{array}{l}\text { Social protection } \\
\text { network draft law }\end{array}$ & $\begin{array}{l}\text { The ministry of state for } \\
\text { the council of } \\
\text { representatives affairs }\end{array}$ & $\begin{array}{l}\text { Woman, household and } \\
\text { childhood/labor and social } \\
\text { affairs committee }\end{array}$ & $1^{\text {st }}$ Reading & $2^{\text {nd }}$ Reading & & \\
\hline 3 & $\begin{array}{c}\text { Child welfare authority } \\
\text { Law }\end{array}$ & $\begin{array}{l}\text { Woman, household and } \\
\text { childhood }\end{array}$ & $\begin{array}{l}\text { Woman, household and } \\
\text { childhood committee }\end{array}$ & & & & \\
\hline 4 & $\begin{array}{l}\text { Ministry of housing } \\
\text { and construction law }\end{array}$ & $\begin{array}{l}\text { The ministry of state for } \\
\text { the council of } \\
\text { representatives affairs }\end{array}$ & $\begin{array}{l}\text { Legal committee labor and } \\
\text { services/woman committees }\end{array}$ & & & & \\
\hline 5 & $\begin{array}{l}\text { Ministry for women } \\
\text { and family affairs law }\end{array}$ & $\begin{array}{l}\text { Ministry of state for } \\
\text { woman affairs }\end{array}$ & Women committee & $1^{\text {st }}$ Reading & $2^{\text {nd }}$ Reading & & \\
\hline 6 & $\begin{array}{l}\text { Social security for the } \\
\text { unemployed law }\end{array}$ & $\begin{array}{l}24 \text { members of } \\
\text { parliament }\end{array}$ & $\begin{array}{c}\text { Woman } \\
\text { committee/financial/legal } \\
\text { committees }\end{array}$ & $1^{\text {st }}$ Reading & & & \\
\hline 7 & $\begin{array}{l}\text { Law of abolition Iraq's } \\
\text { Reservation to article } \\
\text { (9) of the agreement of } \\
\text { abolition all forms of } \\
\text { discrimination against } \\
\text { woman }\end{array}$ & & $\begin{array}{l}\text { Woman committee/foreign } \\
\text { relations committee }\end{array}$ & & & & \\
\hline 8 & $\begin{array}{c}\text { Law of caring for } \\
\text { women without male } \\
\text { provider }\end{array}$ & $\begin{array}{l}\text { Women bloc in the } \\
\text { Iraqi alliance }\end{array}$ & $\begin{array}{l}\text { Woman committee/financial } \\
\text { committee }\end{array}$ & & & & \\
\hline 9 & $\begin{array}{l}\text { National authoring for } \\
\text { the welfare of the } \\
\text { disabled }\end{array}$ & Woman committee & Woman committee & & & & \\
\hline 10 & $\begin{array}{l}\text { Amending the law of } \\
\text { social welfare no. (126) } \\
\text { in } 1980\end{array}$ & Woman committee & Woman committee & & & & \\
\hline 11 & $\begin{array}{l}\text { Law of Orphan's } \\
\text { welfare fund }\end{array}$ & Woman committee & Woman committee & $1^{\text {st }}$ Reading & & & \\
\hline 12 & $\begin{array}{l}\text { Law of banning the } \\
\text { import of violence - } \\
\text { inducing games }\end{array}$ & Woman committee & IWoman committee & $1^{\text {st }}$ Reading & $2^{\text {nd }}$ Reading & & \\
\hline 13 & $\begin{array}{l}\text { Law of accession to the } \\
\text { two optional protocols } \\
\text { to the convention on } \\
\text { the rights of the child }\end{array}$ & & & & & $\begin{array}{c}\text { Hearing } \\
\text { number }(28) \\
\text { of the second } \\
\text { legislative } \\
\text { term }\end{array}$ & $11 / 6 / 2007$ \\
\hline
\end{tabular}

The researchers prepare the table by relying on the Iraqi Parliament website http://www.parliament.iq.

those who serve in Dar Al Hanan for people with severe disabilities. ${ }^{4}$. It recommended caring for the home of the elderlies and an increase in the financial aid

${ }^{4}$ Concerning those with disabilities and those with special needs, the committee, as of its activities in this scoop, participated in a conference about caring for disabled held by the Ministry of Health in $5-6 / 2 / 2009$, as a committee specialized in issuing laws that guarantee caring for the disabled and consolidating their position according to the related articles $n$ the Constitution. 
for those included in social protection network from (50) thousand dinars to (75) thousand dinars which the ministry responded to all. The committee suggested to the council of ministers allocating financial aids for abstemious families because there are no financial allocations for them as the ministry of finance stated. The council of ministers took the suggestion into consideration in laying down the committee's guidelines which devised the necessary procedures to achieve its goals.

The committee collaborated with the ministry of education concerning adding human rights teaching subjects to the school's curricula at all stages to educate students on woman's rights. The ministry responded to the committee's suggestion in the presence of the committee representatives in case of recognition of curriculum. As well, the committee, coordinated with the human rights ministry in following up on the case of women detainees who spent a long time under arrest without due process. The ministry also responded on these cases.

As part of the committee's agenda regarding woman issues, the committee also signed a memorandum of understanding that included a mutual obligation between United Nations Development Fund for Woman (DFW) and the committee. This was signed during a workshop held in Beirut in the time span of 24th to 27th July 2008 by the fund in cooperation with the committee to support woman's issues.

The committee sought to build bridges with the Ministry of State for Women's Affairs in order to find the best solutions to women's issues in Iraq.

\subsection{Second Parliamentary Session}

Table 4 shows suggestions and draft laws of the committee in this session and the forwarded ones from the previous session.

This legislation is still under study as it underwent its first reading on April 4th, 2011 and the second reading on September 20th of the same year. Moreover, the committee held a symposium to debate the law of the Ministry of Women Affairs in cooperation with the media center for civil society organizations. The conference was attended by a number of representatives from civil society organizations that work on woman affairs; as well as the minister of education, labor, and social affairs and a number of university professors.

The committee also worked with the Ministry of State for Women's Affairs to pass the law that makes the ministry has a ministerial portfolio with a budget capable of executing decisions regarding women and family affairs.

A joint meeting was held between the committee and the ministers of labor and social affairs and woman, and the minister of state for the council of representatives affairs to debate the common and overlapping matters regarding the guidelines that secure and facilitate in the work and the powers between the law of women and family affairs. As a result of the joint meeting, the parties met at the meeting e drafted the first amendment to the law of the ministry of labor and social affairs. 
Table 4. Draft laws submitted by the Committee and the Laws approval by Iraqi Parliament in the session of 2010-2014.

\begin{tabular}{|c|c|c|c|c|c|c|c|}
\hline No. & Draft law & The Source & $\begin{array}{l}\text { The committee to } \\
\text { which the draft law } \\
\text { has been forwarded }\end{array}$ & $1^{\text {st }}$ Reading & $2^{\text {nd }}$ Reading & Voting & Approval \\
\hline 1 & $\begin{array}{l}\text { Draft law of social } \\
\text { protection network }\end{array}$ & $\begin{array}{l}\text { Ministry of state for the } \\
\text { council of } \\
\text { representatives affairs }\end{array}$ & $\begin{array}{l}\text { Woman, labor and } \\
\text { social affairs } \\
\text { committees }\end{array}$ & $\begin{array}{l}\text { Hearing no. (51) in } \mathrm{I} \\
4 / 4 / 2011\end{array}$ & $\begin{array}{l}\text { Hearing no. (24) in } \\
22 / 2 / 2012\end{array}$ & & \\
\hline 2 & $\begin{array}{l}\text { Draft law of woman's } \\
\text { ministry and family } \\
\text { affairs }\end{array}$ & $\begin{array}{l}\text { Ministry of state for the } \\
\text { council of } \\
\text { representatives affairs }\end{array}$ & $\begin{array}{l}\text { Woman, and legal } \\
\text { committees }\end{array}$ & $\begin{array}{l}\text { Hearing no. (51) in } \mathrm{H} \\
4 / 4 / 2011\end{array}$ & $\begin{array}{l}\text { Hearing no. (30) in } \\
20 / 9 / 2011\end{array}$ & & \\
\hline 3 & $\begin{array}{l}\text { Caring for woman } \\
\text { without male provider }\end{array}$ & $\begin{array}{l}\text { Women bloc in the } \\
\text { Iraqi Alliance }\end{array}$ & $\begin{array}{l}\text { Woman and financial } \\
\text { committees }\end{array}$ & & & & \\
\hline 4 & $\begin{array}{c}\text { Law of the child welfare } \\
\text { authority }\end{array}$ & Woman committee & Woman committee & & & & \\
\hline 5 & $\begin{array}{l}\text { Law of the disabled } \\
\text { welfare national } \\
\text { authority }\end{array}$ & Woman committee & Woman committee & & & & \\
\hline 6 & $\begin{array}{l}\text { Amending the law of } \\
\text { social welfare no. (126) } \\
\text { in } 1980\end{array}$ & Women committee & $\begin{array}{l}\text { Woman's and legal } \\
\text { committees }\end{array}$ & $\begin{array}{l}\text { Hearing no. (50) in } \\
3 / 4 / 2011\end{array}$ & $\begin{array}{l}\text { Hearing no. (4) in } \\
18 / 6 / 2011\end{array}$ & $\begin{array}{l}\text { Hearing no. } \\
\text { (20) in } \\
7 / 5 / 2013\end{array}$ & \\
\hline 7 & $\begin{array}{c}\text { Draft law of the ministry } \\
\text { of housing and } \\
\text { construction }\end{array}$ & $\begin{array}{l}\text { Ministry of state for the } \\
\text { council of } \\
\text { representatives affairs }\end{array}$ & $\begin{array}{c}\text { Services and } \\
\text { construction and } \\
\text { woman's committee }\end{array}$ & $\begin{array}{l}\text { Hearing no. (8) in } \mathrm{I} \\
2 / 7 / 2011\end{array}$ & $\begin{array}{l}\text { Hearing no. (22) in } \\
20 / 2 / 2012\end{array}$ & $\begin{array}{l}\text { Hearing no. } \\
\quad(30) \text { in } \\
15 / 3 / 2012\end{array}$ & $22 / 4 / 2012$ \\
\hline 8 & $\begin{array}{c}\text { Proposed law of } \\
\text { non-working social } \\
\text { security }\end{array}$ & $\begin{array}{l}24 \text { members of } \\
\text { parliament }\end{array}$ & $\begin{array}{l}\text { Woman and legal } \\
\text { committees }\end{array}$ & $\begin{array}{l}\text { Hearing no. (51) in } \\
4 / 4 / 2011\end{array}$ & & & \\
\hline 9 & $\begin{array}{l}\text { Draft law of abolition of } \\
\text { Iraq's Reservation to } \\
\text { article (9) of the } \\
\text { agreement of abolition } \\
\text { all forms of } \\
\text { discrimination against } \\
\text { woman occurred in act } \\
\text { no. (66) in } 1986\end{array}$ & $\begin{array}{l}\text { Ministry of state for the } \\
\text { council of } \\
\text { Representative affairs }\end{array}$ & $\begin{array}{l}\text { Woman and foreign } \\
\text { relations' committees }\end{array}$ & $\begin{array}{l}\text { Hearing no. (49) in I } \\
2 / 4 / 2011\end{array}$ & $\begin{array}{l}\text { Hearing no. (11) in } \\
16 / 7 / 2011\end{array}$ & $\begin{array}{l}\text { Hearing no. } \\
\text { (35) in } \\
6 / 10 / 2011\end{array}$ & $5 / 12 / 2011$ \\
\hline 10 & $\begin{array}{c}\text { Proposed law of } \\
\text { Orphan's welfare Fund }\end{array}$ & Woman's committee & Woman's committee & $\begin{array}{l}\text { Hearing no. (51) in } \\
4 / 4 / 2011\end{array}$ & & & \\
\hline 11 & $\begin{array}{c}\text { Proposed law of } \\
\text { amending the amended } \\
\text { civil service law no. (24) } \\
\text { in } 1960\end{array}$ & $\begin{array}{l}17 \text { members of } \\
\text { parliament }\end{array}$ & $\begin{array}{l}\text { Women, labor and } \\
\text { social affairs } \\
\text { committees, financial } \\
\text { and legal committees }\end{array}$ & & & & \\
\hline 12 & $\begin{array}{c}\text { Proposed law of } \\
\text { amending the amended } \\
\text { unified pension's law no. } \\
\text { (27) in } 2006\end{array}$ & $\begin{array}{c}19 \text { members of } \\
\text { parliament (MP Zainab } \\
\text { Al Sahlani) }\end{array}$ & $\begin{array}{l}\text { Woman, financial and } \\
\text { legal committees and } \\
\text { labor and social affairs' } \\
\text { committees }\end{array}$ & & & & \\
\hline 13 & $\begin{array}{l}\text { Proposed law of the } \\
\text { disabled and persons } \\
\text { with special needs } \\
\text { welfare }\end{array}$ & $\begin{array}{l}\text { Ministry of state for the } \\
\text { council of } \\
\text { representative affairs }\end{array}$ & $\begin{array}{l}\text { Labor woman's health } \\
\text { committees and } \\
\text { environment and } \\
\text { human rights } \\
\text { committees }\end{array}$ & $\begin{array}{l}\text { Hearing no. (7) in } \mathrm{H} \\
24 / 7 / 2012\end{array}$ & $\begin{array}{l}\text { Hearing no. (36) in } \\
1 / 2 / 2012\end{array}$ & & \\
\hline
\end{tabular}




\section{Continued}

14 Draft law of social
security

\section{Presidency of the} Republic and hearing labor committee, no.(7) and legal in committee 24/7/2012
Woman's committee

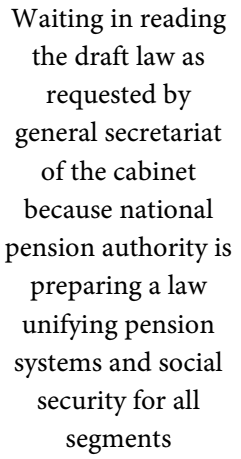

Woman's committee and legal committee for social gender equity
Woman's committee
Law of banning the

16
Hearing no. (2) in

$24 / 2 / 2012$

The researchers prepare the table by relying on the Iraqi Parliament website http://www.parliament.iq.

In addition, the committee also made an objection to the excluding of woman in the independent high electoral commission, in the formation of human rights commission and excluding her from assuming any ministerial portfolio, as she was restricted to a ministry of state without portfolio.

Therefore, the committee invited civil society organizations and the women bloc in the council of the representatives to support a bill demanding an equal representation of woman in the independent high electoral commission and other authorities and institutions as provided in the Iraqi constitution. They also rejected any form of involvement in any commission or authority without any true representation of women as it was granted in the articles $(14,20,49)$ of the Iraqi constitution.

Furthermore, the committee also held a conference to raise concerns about the widowed rights. During the conference, the committee on cooperation with international relief body sponsored by the council of representatives defended the widowed rights to improve their standard of living. The conference also discussed the cases of detained women in the Iraqi prisons and concluded that Al-Tasfirat detention is unhealthy, unqualified, lacking air - conditioners and beds. Thus, the committee recommended that women detainees be transmitted to another place as soon as possible and social workers should be appointed to ensure their well-being.

The committee also hosted meetings with civil society organizations concerned with disabled and persons with special needs to discuss their problems and suggest solutions to improve their reality and the life. Throughout the meeting, the committee's chairman indicated the committee's attempt to enact a law of High Commission on Disabled in spite of the government rejection of this 
law under the pretext of governmental austerity policy. Moreover, the chairman of the committee announced that they are awarding an honorary seat for the disabled women in the committee on condition that she should be elected by her disabled counterparts, to be present and contribute effectively to discuss and issue legislations related to the disabled.

\section{Conclusion: Assessing the Committee}

In observing the formation and work of the committee on women, family, and childhood according to the previous two tables shown above axes, there lie substantive problems within the assessment range that can be summed up in the following points:

\subsection{Regarding the Name of the Committee}

Combining the three components in one committee does not show any benefit, as there is no objective causal connection between them. Putting the burdens of the family and its members on women is incompatible with objective facts on the ground; it also intersects with the growing demands of woman's rights and equality with man. The reality known by all, shows that there are Iraqi women do not have a family, in contrast, there are families without women, therefore, the question becomes what is the significance here of linking women, family and childhood, and excluding the man who supports a family alone. On the other hand, how should there be claims to protect woman's rights and equality with men while the responsibility for caring for the family and its members is solely the responsibility of woman, not man who has an active role in the family that integrates with the role of woman, because the family and its care are a joint responsibility of man and woman.

In an interview with a researcher in the Research Department of Parliament, he told us information that may be unknown to many. The researcher accompanied the process of establishing parliamentary committees and noticed the keenness of all to copy parliamentary experiences in democratic countries in all its details including the committee's names, and reflected it on the Iraqi experience without trying to establish committees emanating from the reality and environment of Iraq and its social and economic conditions that have affected the structure of the family and changed the roles of its members and absented some of them.

\subsection{Regarding the Formation of the Committee}

The committee has also a number of shortcomings according to the formation. First, it formed, in the two sessions, in low rates of membership, as provided by the parliament's rules of procedure, which was seven members, all of them were women. This point leads us to the second shortcoming, the quality of committee's membership.

Unlike other parliament committees whose membership is made of men and women, on the grounds that all issues the parliament and its committee deal 
with, are common issues related to all people sectors, the Committee on the Women, Family, and Childhood formed through the two sessions from women only, as if the issues the committee dealt with are within the concern of women only.

From our view, the membership of the committee should not have been confined to female members of parliament. It should be blended at low rates with male members of parliament, one or two at least, to express opinions of families without women for reasons such as death or divorce or woman's disability. Including more male members from other committees would be mutually beneficial to women's committee and other committees as both deal with various overlapping family issues. This will also allow them to collaborate more effectively with all ministries.

\subsection{Reading the Specialization and Experience of Members}

Article (69) of the twelfth chapter of the parliament's rules of procedure which provided that specialization and experience of the member in forming permanent parliamentary committees are to be taken into consideration, i.e., committee members should be specialized in family matters such as (sociology, psychology, education, etc.) and other related fields, it is noticed that committee members' specialization is restricted to pure sciences approximately in a percentage of $90 \%$ which created a difficulty for members of the committee to face related problems concerning it. Moreover, it is an obvious indication of the violation of the parliament's rules of procedure. Moreover, it is evident that parliament is not concerned with this Committee because the parliament has not strictly applied its rules of procedure.

\subsection{Reading on Replacement of Committee Members}

This paper observed changes in the formation of the committee during the two parliamentary sessions (as it is shown in the tables of the first axis) and noticed that in all cases it did not replace the member (who left the committee for one reason or another) with another from the same bloc. For example, in the first parliamentary session, the member Nidhal Ta'an from Badr organization/Unified Iraqi Alliance was replaced (because of her death) with (Lamiaa Naeema Dawood) from Independent/Unified Iraqi-Alliance bloc. In the second session, Samira Al-Musawi from Independents/National Alliance, Fayza Al-Obaidi and Lubna Khemees ${ }^{5}$, both from Accord party/Iraqiya Alliance, were replaced with Amel Sahib, Haifa Majli, and Manal Hameed Hashim ${ }^{6}$ who were

\footnotetext{
${ }^{5}$ The name Lubna Khamees mentioned in two committees in the record of the parliament meeting (No.24) on seventeenth of January 2011, first one in Committee on Tourism and Relics, and the second one the Committee on the Women, Family, and Childhood.

${ }^{6}$ It should be noted that the names of those three members mentioned in other committees in the record of the meeting (24), Amel Sahib was a member of Committee on Construction and Services, Haifa Majli was a member in the Committee on Agriculture and Water, Manal Hameed was a member in the Committee on Economic and Investment, all of them were transferred from these committees to the second one the Committee on the Women, Family, and Childhood, to fill the places of the withdrawn members.
} 
all from the National Alliance. The selection of the members was apparently random because the formation of the committee did not represent all parliamentary blocs. For example, in the second session, the committee consisted of members from two blocs only: the National Alliance with five members and Iraqiya Alliance with two members: the chairman and vice-chairman.

The above changes also indicate that political blocs are not interested in the committee and its work, otherwise, the bloc insisted on replace the absent member for any reason by another one from the same bloc, and on most blocs, if not all, to be representative in the committee. However, this explains two important issues:

The first one is negative, the indifference of political blocs to the committee, as it doesn't any political gain.

The second one is positive, this indifference to the committee by political blocs represented in the parliament can give a greater space to the movement of committee members in their work as they will be outside the framework of political consensus that could happen among blocs.

However we should ask our self the following question: do the committee members employ that freedom and movement space in their work in proposing laws and passing them on, especially if those draft laws are not in need of political consensus in one hand, and they are not critical draft laws that can cause any problems among political blocs on the other hand? This question demands to notice the following:

1) Out of thirteen drafts and proposed laws, the committee passed, in the first parliamentary session, only one law: the law of accession to the two Optional Protocols to the Convention on the Rights of the Child, which was considered to be a very low percentage, despite the importance of the law. In this session, the Committee was able to suspend the work of clause fourteen of article seventeen of the Rent Law No.87 in 1979, this cancellation was approved and is currently in force.

In the second parliamentary session, the committee passed four draft laws out of sixteen drafts and proposed laws; two of which were approved and come into effect. One of them, the law of the ministry of housing and construction that had no relation to the committee, the other two are waiting for approval after they had been passed on to the parliament by voting. It is noteworthy to mention that the four laws are forwarded from the first parliamentary session to the second, i.e., they are not proposed in the second session.

By counting the total draft and proposed laws suggested by the committee to the parliament in the two sessions which were seventeen, as some of them were forwarded from the first to the second session, and five of which were passed on, the percentage would be (29\%) over eight years which is a very small percentage.

2) Basing on the proportion of draft laws passed on during the two parliamentary sessions, taking into account the composition and chairmanship of the Committee, it is obvious that there had been no interest in the committee and 
had a lower share in the political quota among parliament blocs. It is known to that entire Iraqi parliament for two successive sessions had a majority of members belonged to the Unified Iraqi Alliance in the first session and the National Alliance in the second, but the committee, whose chairman in the first session was from the Unified Iraqi Alliance, could pass on only one law. While in the second session, whose chairman was from Iraqiya Alliance, it could pass on four laws. In other words, it was outside of political tensions, but it lost numerous opportunities to activate its role in the parliament due to its inactivity.

3) Out of seventeen draft and proposed laws presented by the committee during the two parliamentary sessions, the woman had her share in three laws only, the committee could pass on only one law, which was the proposed law of abolition of Iraq's reservation to the article (9) of CEDAW, occurred in the act no. (66) in 1986. This was suggested in the first parliamentary session and was passed on to the second session. While the other two laws-which were suggested in the first parliamentary session too-are laws of the ministry on women and family affairs that had two readings, and the law of caring for the woman without breadwinner received no reading, both were not approved until this date.

4) Proposed and draft laws show an intersection of the committee's work with other parliamentary committees' such as the Paralympics committee, which is sports activity for disabled person, Committee on Human Rights, and Committee on Labor and Social Affairs. As a result, the committee's work is not plain and limited to its specialty. It overlaps with other parliamentary committees' work, which makes matter more confusing, and the committee was not entirely focusing on its work and leading it to be less effective on its own task. The mentioned law of the ministry relating to housing and construction was an obvious example to testify to the problems with the women's committee.

All these observations mentioned in the paper give us the perception that the Committee is intended to be merely complementary to the work of other committees. Due to this problem, the committee is deactivated and had no basic and chief role in consolidating parliament's legislative and supervisory role.

The quantity and quality of proposed and draft laws suggested by the committee to the parliament observed during the two parliamentary sessions also showed that the committee was inactive in raising issues relevant directly to its work and specialization, and it was passive in relation to passing draft laws due to lack of expertise of members on most pressing social issues such as women issues which was rather to the committee to deal with effectively, and move away from the secondary issues that are not of its specialty and left to the competent committees.

On the basis of the problems that we described above and the quality of proposed and draft laws that the committee had reviewed throughout the two parliamentary sessions; it was suggested to combine the women's committee with labor and social affairs committee. This new committee would be the named: 
"Committee on Economic and Social Development", which will be responsible for all matters of social welfare and economic development in the country, rather than a committee with a name of a particular component, and does not work to pose its issues effectively.

\section{References}

Al-Moussawi, S. J. (2009). Towards a Future Vision for the Process of Change and Social Development in the Field of Women and Childhood: An Attempt to Change and Develop the Iraqi Social Structure for the Advancement of Women and Children/Baghdad.

Alnidawy, N. (2010). Parliamentary Performance of Iraqi Woman: A Study and Evaluation. Baghdad: Al-Tabaa Press.

Jawad, B. M. (2012). Role of Iraqi Woman in the Democratic System: An Analytical Study of Women's Parliamentary Behavior, Dar Al-Harb, Syria.

Salman, A. (2008). The Role of Iraqi Woman in the Iraqi Parliament Since 2003. Baghdad: The Parliament/Research Department. 